\title{
PERAN INDUSTRI KAYU LAPIS TERHADAP PENYERAPAN TENAGA KERJA LOKAL DI KELURAHAN URUG KECAMATAN KAWALU KOTA TASIKMALAYA
}

\author{
Cahya Darmawan ${ }^{1}$, Ayu Salha Deyana ${ }^{2}$, Siti Fadjarajani ${ }^{3}$ \\ 1,2,3 Program Studi Pendidikan Geografi, Pascasarjana, Universitas Siliwangi \\ e-mail: cahyadarmawan81@gmail.com
}

\begin{abstract}
An industry usually does not return much attention to the condition of society to convert workers which requirement have special skills, adequate abilities, and high school graduates, but the plywood industry in Urug Village absorbs a lot of labor in the region. The life of the people in the area is becoming increasingly complex, causing a transition from the old conditions before it became an industrial area. This research uses qualitative method with a descriptive approach. The population of this study was 2,581 households in Urug Village. The sample used is $2 \%$ of the total population of as many as 52 people. The results of this research are industrial raw materials plywood obtained by supply, the dominant workforce comes from Urug Village, the technology used in the plywood manufacturing process is modern, the industrial location is easy to reach, the production is marketed for export, the dominant workforce comes from the Kelurahan. Urug is inseparable from the policies issued by the village and local community leaders, and the existence of the plywood industry increases the income of workers.
\end{abstract}

Keywords: Industry, Plywood, Local Labor, Urug Village.

\begin{abstract}
Abstrak: Suatu industri biasanya tidak terlalu memperhatikan kondisi masyarakat untuk menjadi pekerja yang harus memiliki keahlian khusus, kemampuan yang memadai, dan lulusan sekolah tinggi, tetapi industri kayu lapis di Kelurahan Urug banyak menyerap tenaga kerja pada wilayah tersebut. Kehidupan masyarakat di kawasan tersebut menjadi semakin kompleks sehingga menimbulkan suatu perubahan dari kondisi lama sebelum menjadi kawasan industri. Penelitian menggunakan metode kualitatif dengan pendekatan deskriptif. Populasi dari penelitian ini adalah $2.581 \mathrm{KK}$ yang terdapat di Kelurahan Urug. Sampel yang digunakan yaitu $2 \%$ dari total populasi atau sebanyak 52 orang. Hasil penelitian ini adalah bahan baku industri kayu lapis didapatkan dengan cara dipasok, tenaga kerja dominan berasal dari Kelurahan Urug, teknologi yang digunakan pada proses pembuatan kayu lapis sudah modern, lokasi industri mudah dijangkau, hasil produksi dipasarkan secara ekspor, tenaga kerja dominan berasal dari Kelurahan Urug tidak terlepas dari kebijakan yang dikeluarkan oleh pihak kelurahan dan tokoh masyarakat sekitar, dan dengan adanya industri kayu lapis meningkatkan pendapatan para pekerja.
\end{abstract}

Kata Kunci: Industri, Kayu Lapis, Tenaga Kerja Lokal, Kelurahan Urug

\section{PENDAHULUAN}

Dunia industri di Indonesia saat ini telah berkembang sangat pesat, seperti beragamnya teknologi sebagai fasilitator untuk pengolahan sumber daya alam hayati maupun non hayati. Namun perkembangan tersebut harus diimbangi pula dengan kualitas sumber daya manusia yang memadai.

Indonesia yang termasuk kedalam kategori negara berkembang, pada saat ini tak bisa dipungkiri lagi dengan kemajuan dibidang industrinya. Pada pertumbuhan ekonomi, kualitas Indonesia masih rendah dengan ditunjukan oleh ketidakmampuan pertumbuhan ekonomi untuk menyerap pengaturan yang ada maupun terhadap tambahan tenaga kerja baru. Besarnya jumlah pengangguran ini tentunya berimplikasi pada peningkatan kesejahteraan masyarakat yang ditunjukkan dengan masih tingginya angka kemiskinan (Silalahi, 2009). Dengan demikian, diperlukan tingkat pertumbuhan ekonomi yang lebih tinggi lagi untuk dapat mengurangi tingkat pengangguran 